\title{
Pengelolaan Pembibitan Tanaman Kelapa Sawit (Elais guineensis Jacq.) Di Kebun Bangun Bandar, Sumatera Utara
}

\section{Management Oil Palm (Elaeis quineensis Jacq.) Nursery in Bangun Bandar Estate, North Sumatera}

\author{
Rahayu Novrina Rosa dan Sofyan Zaman*
}

\author{
Departemen Agronomi dan Hortikultura, Fakultas Pertanian, Institut Pertanian Bogor \\ (Bogor Agricultural University), Jl. Meranti, Kampus IPB Darmaga, Bogor 16680, Indonesia \\ Telp.\&Faks.62-251-8629353 e-mail agronipb@indo.net.id \\ *Penulis untuk korespondensi: sofyan_zaman@yahoo.com
}

Disetujui 6 November 2017/Published online 14 November 2017

\begin{abstract}
The research was done in Bangun Bandar Estate, North Sumatera for three months, began on 13 Februari 2012 to 12 Mei 2012. The purpose of this research was to improve technical and managerial skill. The data were gained are primary data (direct method) and secondary data (indirect method). Primary data is all information obtained directly from observations by the author on the observation height, stem diameter, leaf midrib to the number of seeds in pre nursery. Observation of the number of died seeds (rot and brown), direct observation to determine the technical activities. In the field and compared with the standard, as well as direct discussions with unions and staff about the palm oil. Secondary data obtained from the farm's collection such as daily reports, monthly reports, annual reports and archives garden. Secondary data includes climate, productivity, fertilizer, recommendation, organizational structure and matters relating to labor. Based on observation, in general nursery management at the estate was going well although there are still some problems that occur in the field. The percentage of plants that grew well in 2 weeks to weeks transport, which reaches $95.98 \%$ so that the sprouts are grown very well, the plants will use as planting material.
\end{abstract}

Keywords : nursery, oil palm, primary data, secondary data

\begin{abstract}
ABSTRAK
Penelitian ini dilakukan di Bangun Bandar Estate, Sumatera Utara selama tiga bulan, dimulai pada 13 Februari 2012-12 Mei 2012. Tujuan dari penelitian ini adalah untuk meningkatkan keterampilan teknis dan manajerial. Data yang diperoleh adalah data primer (metode langsung) dan data sekunder (metode tidak langsung). Data primer adalah semua informasi yang diperoleh langsung dari pengamatan penulis pada ketinggian pengamatan, diameter batang, daun pelepah untuk jumlah biji di pra pembibitan. Pengamatan jumlah bibit mati (membusuk dan coklat), observasi langsung untuk menentukan kegiatan teknis. Di lapangan dan dibandingkan dengan standar, serta diskusi langsung dengan serikat pekerja dan staf tentang kelapa sawit. data sekunder yang diperoleh dari koleksi peternakan seperti laporan harian, laporan bulanan, laporan tahunan dan arsip taman. Data sekunder meliputi iklim, produktivitas, pupuk, rekomendasi, struktur organisasi dan hal yang berhubungan dengan tenaga kerja. Berdasarkan pengamatan, dalam manajemen pembibitan umum di estate akan baik meskipun masih ada beberapa masalah yang terjadi di lapangan. Persentase tanaman yang tumbuh dengan baik dalam 2 minggu untuk transportasi minggu, yang mencapai 95,98\% sehingga kecambah tumbuh dengan sangat baik, tanaman akan digunakan sebagai bahan tanam.
\end{abstract}

Kata kunci : data primer, data sekunder, kelapa sawit, pembibitan 


\section{PENDAHULUAN}

Kelapa Sawit (Elaeis guinensis Jacq.) adalah salah satu jenis tanaman dari famili Arecaceae yang menghasilkan minyak nabati yang dapat dimakan (edible oil). Saat ini, kelapa sawit sangat diminati untuk dikelola dan ditanam. Daya tarik penanaman kelapa sawit masih merupakan andalan sumber minyak nabati dan bahan agroindustri (Sukamto, 2008).

Dalam perekonomian Indonesia komoditas kelapa sawit memegang peranan yang cukup strategis karena komoditas ini mempunyai prospek yang cerah sebagai sumber devisa. Disamping itu, minyak sawit merupakan bahan baku minyak utama minyak goreng yang banyak di pakai di seluruh dunia, sehingga secara terus menerus dapat menjaga stabilitas harga minyak sawit. Komoditas ini pun mampu menciptakan kesempatan kerja yang luas dan meningkatkan kesejahteraan masyarakat (Mangoensoekarjo dan Semangun, 2003).

Perkembangan perkebunan kelapa sawit di Indonesia mengalami kemajuan pesat. Luas areal dan produksi tanaman kelapa sawit yang diusahakan oleh perkebunan diseluruh indonesia mengalami peningkatan selama lima tahun terakhir, yaitu pada tahun 2005 luas areal sawit mencapai 5453817 ha dgn produksi Crude Palm Oil (CPO) sebesar 11861615 ton dan mengalami peningkatan luas areal menjadi 8430027 ha dengan produksi CPO 20615958 ton pada tahun 2010 (Direktorat Jenderal Perkebunan, 2011).

Peningkatan produksi kelapa sawit tersebut perlu lebih diupayakan lagi guna menghadapi era perdagangan bebas. Salah satunya adalah peningkatan produksi dari segi budidaya tanaman. Menurut Sukamto (2008) produksi kelapa sawit Indonesia yang telah mampu melampaui produksi kelapa sawit Malaysia sebenarnya disebabkan oleh adanya perluasan area tanam, bukan karena faktor produktivitas. Rata-rata produktivitas tanaman kelapa sawit nasional hanya mencapai 15 ton TBS per hektar per tahun, sedangkan produktivitas tanaman kelapa sawit di Malaysia telah menembus angka 25 ton TBS per hektar per tahun. Kondisi semacam ini, produktivitas kelapa sawit masih dapat ditingkatkan lagi dengan beberapa kiat, salah satunya dengan persiapan benih dan pembibitan. Selanjutnya PPKS (2003) menambahkan bahwa pembibitan merupakan langkah awal dari seluruh rangkaian kegiatan budidaya tanaman kelapa sawit.

Salah satu aspek yang perlu mendapatkan perhatian secara khusus dalam menunjang program pengembangan areal tanaman kelapa sawit adalah penyediaan bibit yang sehat, potensinya unggul dan tepat waktu. Faktor bibit memegang peranan penting dalam menentukan keberhasilan penanaman kelapa sawit. Kesehatan tanaman masa pembibitan mempengaruhi pertumbuhan dan tingginya produksi selanjutnya, setelah ditanam di lapangan. Oleh karena itu, teknis pelaksanaan pembibitan perlu mendapat perhatian besar dan khusus (PPKS, 2006). Tujuan khusus dari kegiatan penelitian ini adalah untuk meningkatkan pemahaman, keterampilan teknis dan manajemen pembibitan tanaman kelapa sawit, serta mempelajari dan menganalisis kegiatan pengelolaan pembibitan tanaman kelapa sawit di perkebunan.

\section{BAHAN DAN METODE}

Kegiatan penelitian ini dilaksanakan di PT Socfindo, Perkebunan Bangun Bandar Medan, Sumatera Utara, dimulai pada tanggal 13 Februari 2012 sampai 12 Mei 2012. Metode penelitian yang digunakan pada kegiatan penelitian adalah metode langsung dan tidak langsung yang bertujuan untuk memperoleh data primer dan data sekunder. Metode yang dilakukan adalah melakukan praktik kerja langsung di lapangan dengan turut bekerja aktif dalam pelaksanaan kegiatan perusahaan atas izin perusahaan seperti menjadi karyawan harian lepas (KHL) selama tiga minggu, kemudian bertindak sebagai pendamping mandor pada tiga minggu berikutnya dan sebagai pendamping asisten pada enam minggu berikutnya, serta melakukan pengamatan dan diskusi. Pendekatan tidak langsung dilakukan melalui pengumpulan data-data di perkebunan berupa laporan bulanan, laporan tahunan, dan arsip-arsip kebun lainnya.

Data primer diperoleh dengan melakukan pengamatan langsung di lapangan terhadap semua kegiatan yang berlangsung di perkebunan. Kegiatan yang berlangsung tiap harinya dituliskan dalam jurnal harian selaku KHL, pendamping mandor, dan pendamping asisten. Data pengamatan lapangan difokuskan pada kegiatan pengelolaan pembibitan yaitu pada kegiatan pembibitan awal (pre nursery) dan pembibitan utama (main nursery). Beberapa pengamatan langsung yang dikumpulkan penulis sebagai data primer seperti :

1. Pengamatan terhadap jumlah bibit yang mati (Daya tumbuh bibit).

Data ini akan digunakan untuk mengetahui daya tumbuh varietas dari kecambah yang digunakan. Dengan demikian, dapat diketahui kualitas dari kecambah itu sendiri serta upaya-upaya 
perbaikan dalam menekan angka kematian kecambah tersebut.

2. Pengamatan tinggi, diameter batang dan jumlah pelepah daun untuk bibit di pre nursery.

Data tersebut akan digunakan untuk mengetahui pertumbuhan vegetatif bibit kelapa sawit pada umur bibit tanaman yang berbeda. tiap pembibit itu diamati 20 tanaman contoh untuk setiap bedeng.

Tinggi tanaman, diameter batang dan jumlah pelepah diukur setelah tanaman berumur 1 minggu dan dilakukan setiap 1 minggu sekali. Tinggi tanaman dengan menggunakan mistar dari pangkal batang hingga ujung daun yang tertinggi dan telah diluruskan. Diameter batang diukur dengan menggunakan jangka sorong sekitar $1 \mathrm{~cm}$ dari permukaan tanah dengan cara mengukur dua sisi batang yang berlawanan, nilainya dijumlahkan lalu dirata-ratakan. Pelepah daun yang dihitung hanya daun yang berwarna hijau dan telah membuka sempurna. Tanaman yang diukur adalah tanaman sampel. Pengukuran dilakukan dari 2 MST hingga tanaman berumur $10 \mathrm{MST}$.

3. Pengamatan terhadap seluruh kegiatan teknis di lapangan.

Pengamatan ini akan dilakukan secara langsung untuk mengetahui kegiatan teknis di lapangan dan dibandingkan dengan standar dan literatur yang ada, kemudian akan dianalisis secara deskriptif.

Data sekunder diperoleh dari pengumpulan data di perkebunan seperti laporan harian, laporan bulanan, laporan tahunan, serta arsip kebun. Kondisi dan kegiatan umum di perkebunan memerlukan data seperti : peta kebun, curah hujan, kondisi lahan dan tanaman, produksi dan produktivitas kebun, struktur organisasi dan lain-lain. Sementara untuk yang berhubungan dengan aspek khusus pengelolaan pembibitan diperlukan data sekunder seperti : kondisi lahan pembibitan, kondisi bibit, umur bibit tanaman pada setiap blok areal pembibitan, hasil pekerjaan, serta data atau informasi lain yang diperlukan. Data tersebut dibutuhkan untuk menganalisis beberapa kegiatan di pembibitan, secara deskriptif dan dibandingkan dengan sumber pustaka yang baku.

\section{Kondisi umum kebun}

Kebun Bangun Bandar terletak di kecamatan Dolok Masihul, Kabupaten Serdang Bedagai, provinsi Sumatera Utara. Topografi lahan datar hingga bergelombang dengan ketinggian 0 - $50 \mathrm{~m}$ di atas permukaan laut. Peta letak administrasi kebun Bangun Bandar dapat dilihat pada Lampiran 1. Sebelah utara lokasi kebun Bangun Bandar berbatasan dengan kota Dolok Masihul, di sebelah selatan berbatasan dengan kampung Bukit Cermin, sebelah timur berbatasan dengan Kampung Bantan dan sebelah barat berbatasan dengan kebun Silau Dunia.

Bangun Bandar mempunyai lahan 4 649.00 ha dengan luas areal hak guna usaha (HGU) 4560.62 ha dan non HGU 88.38 ha. Dari areal HGU tersebut, lahan yang telah ditanami kelapa sawit hanya sekitar 3335.64 ha dan tanaman karet sekitar 1224.98 ha. Hal ini disebabkan karena adanya areal yang dijadikan sebagai sarana dan prasarana seluas 88.38 ha. Luas areal terdiri dari TM 2160.4 ha, TBM 897.49 ha, TB 277.75 ha dan sarana 88.38 ha (Kantor Bangun Bandar, 2012).

Kebun ini memiliki 16 kebun yang terdiri atas 11 perkebunan kelapa sawit dan 5 (lima) perkebunan karet. Perkebunan-perkebunan ini terletak di Provinsi Nanggroe Aceh Darussalam sebanyak 4 kebun dan di Provinsi Sumatera Utara sebanyak 12 kebun.

Tanaman kelapa sawit yang dibudidayakan di Bangun Bandar PT. Socfindo adalah varietas Tenera, hasil persilangan Dura dan Pisifera, yang seluruhnya berasal dari Tenera Socfindo. Pola tanam yang digunakan untuk penanaman kelapa sawit di Bangun Bandar adalah pola tanam segitiga sama sisi dengan jarak tanam yang digunakan adalah $9.0 \mathrm{~m}$ x $9.0 \mathrm{~m}$ x $9.0 \mathrm{~m}$ dengan jarak antar barisan $7.8 \mathrm{~m}$ sehingga populasi per hektarnya 143 pokok.

Kondisi tanah yang ada di kebun kelapa sawit Bangun Bandar didominasi oleh tanah aluvial dan podzolik merah kuning (PMK) 60\%$70 \%$ dan sebagian kecil tanah gambut. Ciri-ciri tanah aluvial mempunyai tekstur pasir dan debu kurang dari 40 \%. Tanah PMK berasal dari tanah podzolik coklat yang mengalami sedikit perubahan pengaruh podzolosasi. Warna dominan merah dan kuning disebabkan oleh besi yang dioksidasi dan dihidrasikan.

Daerah ini termasuk beriklim sangat basah dan mempunyai kisaran suhu $24^{\circ} \mathrm{C}-28^{\circ} \mathrm{C}$. Rata-rata curah hujan dan rata-rata hari hujan selama sepuluh tahun (2001 - 2011), yaitu 2 $285.6 \mathrm{~mm}$ dan 139.1 hari hujan dengan 60.3\% nilai Q. 


\section{HASIL DAN PEMBAHASAN}

\section{Kondisi Umum Pembibitan}

Pengamatan pembibitan awal (pre nursery) kelapa sawit terletak pada lahan 2 ha pada divisi V. Pada lahan 2 ha ini bibit yang ditanam adalah bibit pre nursery yang dikhususkan untuk dijual. Bahan tanam berasal dari Pusat Seleksi Bangun Bandar (PSBB). Pada saat dilaksanakannya penelitian penulis melakukan kegiatan pengamatan pada divisi V, sedangkan pada kegiatan lain penulis ditempatkan pada Divisi I.

Sistem pembibitan yang digunakan adalah sistem pembibitan dua tahap, untuk kondisi di Indonesia PT. Socfindo merekomendasikan pembibitan D x P Unggul Socfindo dengan cara dua tahap (Doble stage) dikarenakan ukuran kecambah PT. Socfindo yang relatif kecil dan memerlukan penanganan yang teliti agar diperoleh bibit yang bermutu baik.

Pada pembibitan dua tahap yang dilakukan ini, kecambah ditanam pada plastik polibag yang mempunyai ukuran $15 \mathrm{~cm}$ x $20 \mathrm{~cm}$, tebal $0.10 \mathrm{~mm}$ dengan lubang perforasi sebanyak 18 buah untuk mengatur drainase. Polibag yang diisi sebaiknya menggunakan media tanah tanah lapisan atas (top soil) yang gembur, subur, bersih dari potongan kayu dengan cara diayak serta banyak mengandung bahan organik dan diambil dari lahan yang bebas serangan penyakit terutama penyakit ganoderma. Seminggu sebelum penanaman dilakukan, pengisian tanah ke polibag telah selesai dilaksanakan. Setelah itu polibag yang telah berisi tanah disusun rapat dan rapi membentuk bedengan dengan ukuran 10 kantong melebar dan panjangnya tergantung kepada jumlah bibit per nomor kelompok kategori.

Pemeliharaan bibit meliputi penyiraman, penyiangan, pemupukan dan pengendalian hama dan penyakit tanaman. Penyiraman dilakukan dua kali sehari yaitu pada pagi dan sore hari tetapi tergantung curah hujan yang turun. Tiap kali penyiraman dibutuhkan air sampai dengan kapasitas lapang. Penyiangan gulma dilakukan terhadap gulma yang tumbuh di polibag dan di sekitar polibag. Penyiangan dilakukan secara manual dan rotasinya tergantung kepada kecepatan pertumbuhan gulma di lapangan. Pemupukan pertama dilakukan pada umur 4 MST, kemudian pemberian pupuk selanjutnya dengan interval 1 minggu sekali. Pupuk yang digunakan adalah pupuk Urea dan NPK dan diaplikasikan dalam bentuk larutan dengan menggunakan gembor.

\section{Daya Tumbuh Kecambah}

Bahan tanaman (benih) memiliki kontribusi input 7 - $8 \%$ dari total investasi awal, namun kualitas dan karakteristiknya merupakan hal yang sangat krusial dalam mempengaruhi proses pertumbuhan dan produktivitas secara keseluruhan. Pertumbuhan dan vigor bibit sangat ditentukan oleh kecambah yang ditanam, morfologi kecambah serta cara penanamannya (Pahan, 2010).

Kebun Bangun Bandar hanya melepas 2 (dua) varietas bahan tanaman kelapa sawit unggul yaitu DxP Unggul Socfindo (L) dan DxP Unggul (Y) yang sudah terdaftar dan diakui oleh Pemerintah Republik Indonesia. Dalam memproduksi kedua varietas tersebut PT. Socfindo menggunakan sistem kategori. Pengelompokan berdasarkan kategori ini bertujuan untuk mendapatkan tanaman dengan fenotype (penampilan fisik) yang sama dan pertumbuhan tinggi yang relatif homogen. DxP Unggul Socfindo (L) dicirikan dengan buah yang bercangkang tipis dengan daging buah yang tebal, sedangkan DxP Unggul (Y) adalah buah yang bercangkang tebal dan daging buah yang tipis. Daya tumbuh bibit dapat dilihat pada kecambah yang telah ditanam pada Tabel 1 .

Data Tabel 1 diketahui bahwa daya tumbuh kecambah DxP Unggul Socfindo pada pengamatan yang dilakukan pada saat 2 MST hingga 10 MST cukup tinggi yaitu 95.98\%. PPKS (2000) menyatakan bahwa bahan tanam yang berkualitas baik dan pengelolaan pembibitan awal yang baik, jumlah bibit yang mati tidak melebihi $10 \%$ dari total bibit yang ditanam. Kesalahankesalahan dalam penanaman harus diperhatikan karena akan menimbulkan kelainan pada bibit. Kesalahan pada bibit seperti ditemukannya kecambah yang plumula atau radikula patah pada saat proses penanaman tetapi tidak dipisahkan atau tetap ditanam. Penanaman kecambah itu seharusnya dilakukan secara hati-hati, karena plumula dan radikula kecambah mudah patah serta jika terdapat kecambah yang dari awalnya sudah mengalami patah plumula atau radikula, maka sebaiknya dipisahkan dan dilaporkan kepada asisten. 
Tabel 1. Daya Berkecambah Bibit PT. Socfindo

\begin{tabular}{|c|c|c|c|c|c|c|c|}
\hline \multirow[t]{2}{*}{ Tanggal tanam } & \multicolumn{2}{|c|}{ No. kategori } & \multirow{2}{*}{$\begin{array}{c}\text { Total } \\
\text { ditanam }\end{array}$} & \multicolumn{2}{|c|}{ Kecambah mati } & \multirow{2}{*}{$\begin{array}{l}\text { Kecambah } \\
\text { hidup }\end{array}$} & \multirow{2}{*}{$\begin{array}{c}\text { Daya } \\
\text { kecambah } \\
(\%)\end{array}$} \\
\hline & DPL & DPY & & DPL & DPY & & \\
\hline $25-01-2012$ & 4200 & 800 & 5000 & 200 & 30 & 4770 & 95.4 \\
\hline 02-02-2012 & 5000 & 5000 & 10000 & 300 & 200 & 9500 & 95.0 \\
\hline 03-02-2012 & 5000 & 0 & 5000 & 290 & 0 & 4710 & 94.2 \\
\hline 06-02-2012 & 0 & 5000 & 5000 & 0 & 269 & 4731 & 94.62 \\
\hline 09-02-2012 & 8600 & 1400 & 10000 & 355 & 0 & 9645 & 96.45 \\
\hline $15-02-2012$ & 5000 & 0 & 5000 & 90 & 0 & 4910 & 98.2 \\
\hline 21-02-2012 & 1700 & 8300 & 10000 & 84 & 400 & 9516 & 95.16 \\
\hline $\begin{array}{l}26-02-2012 \\
07-03-2012\end{array}$ & $\begin{array}{l}5000 \\
5200 \\
\end{array}$ & $\begin{array}{l}5000 \\
4800 \\
\end{array}$ & $\begin{array}{l}10000 \\
10000\end{array}$ & $\begin{array}{l}100 \\
163 \\
\end{array}$ & $\begin{array}{l}158 \\
100 \\
\end{array}$ & $\begin{array}{l}9742 \\
9737\end{array}$ & $\begin{array}{l}97.42 \\
97.37\end{array}$ \\
\hline Rata-rata & & & & & & & 95.98 \\
\hline
\end{tabular}

Kesalahan lain yang banyak ditemukan ditandai dengan akar bibit yang terbongkar karena penanaman yang terlalu dangkal. Kesalahan ini banyak ditemukan karena pekerja banyak yang ingin menyelesaikan pekerjaan secara cepat. Untuk mencegah hal ini maka konsolidasi pembibitan awal perlu dilakukan setiap hari. Pada saat kegiatan penelitian ini berlangsung, penulis mengikuti penanaman pada tanggal 15 Februari 2012, penulis mencoba melakukan konsolidasi ini setiap 2 hari sekali sampai dengan 2 MST atau penyeleksian kecambah mati ini dilakukan. Seleksi bibit mati yang dilakukan dari 2 MST hingga 10 MST, kecambah yang mati hanya 90 dari 5000 kecambah yang ditanam. Selanjutnya, dari faktor kesalahan manusia (human error) dapat dikurangi dengan cara memberikan pengawasan yang lebih lagi oleh mandor pada saat proses penanaman berlangsung.

\section{Pertumbuhan Vegetatif Bibit}

Selama penulis penelitian di PT. Socfindo, pengamatan dilakukan dari 1 MST hingga 10 MST atau diperkirakan sampai bibit berumur 2.5 bulan. Pengamatan dilakukan sampai umur 10 MST dikarenakan bibit yang diamati sudah diangkut oleh pembeli. Pengamatan keragaan bibit dengan cara pengukuran vegetatif sederhana merupakan cara yang sederhana untuk mengetahui kualitas bibit yang ditanam (PPKS, 2000). Pertumbuhan vegetatif bibit yang ditanam pada tanggal 15 Februari 2012 dapat dilihat pada kenaikan pertumbuhan dengan grafik berikut. Tinggi tanaman merupakan ukuran pertumbuhan tanaman yang paling sering diamati baik sebagai indikator pertumbuhan maupun sebagai variabel yang digunakan untuk mengukur pengaruh lingkungan. Tanaman dapat dikatakan baik apabila pertumbuhan tinggi tanaman baik dan tidak kerdil ataupun tidak terlalu cepat. Tinggi tanaman memperlihatkan pertumbuhan vegetatif suatu tanaman. Tinggi tanaman diukur mulai dari permukaan tanah hingga daun tanaman tertinggi dan dilakukan sebanyak 10 kali pengamatan yang dilakukan kemudian dianalisa dengan menggunakan analisis regresi.

Menurut Mangoensoekarjo dan Semangun (2005) jaringan penyimpan makanan pada tanaman kelapa sawit disebut dengan endosperm. Endosperm pada kelapa sawit tidak pernah keluar dari cangkang, melainkan diserap oleh haustorium sebagai sumber energi untuk pertumbuhan perkecambahan. Pada saat 1 MST telah muncul akar, namun sumber makanan yang digunakan hanya berasal dari cadangan makanan sehingga pasokan energi benar-benar tercukupi hingga minggu ke-4 untuk pemanjangan plumula dan radikula. Setelah minggu ke-5 bibit kelapa sawit mulai mengambil unsur hara dan mineral dari tanah sehingga pertumbuhan menjadi stabil. Terlihat bahwa pertumbuhan bibit kelapa sawit mengalami kenaikan tertinggi pada minggu ke-4 menuju ke-5 yaitu $5.86 \mathrm{~cm}$ menjadi $8.22 \mathrm{~cm}$ kemudian mengalami kenaikan yang stabil pada minggu ke-6 dan seterusnya (Lampiran 10). 


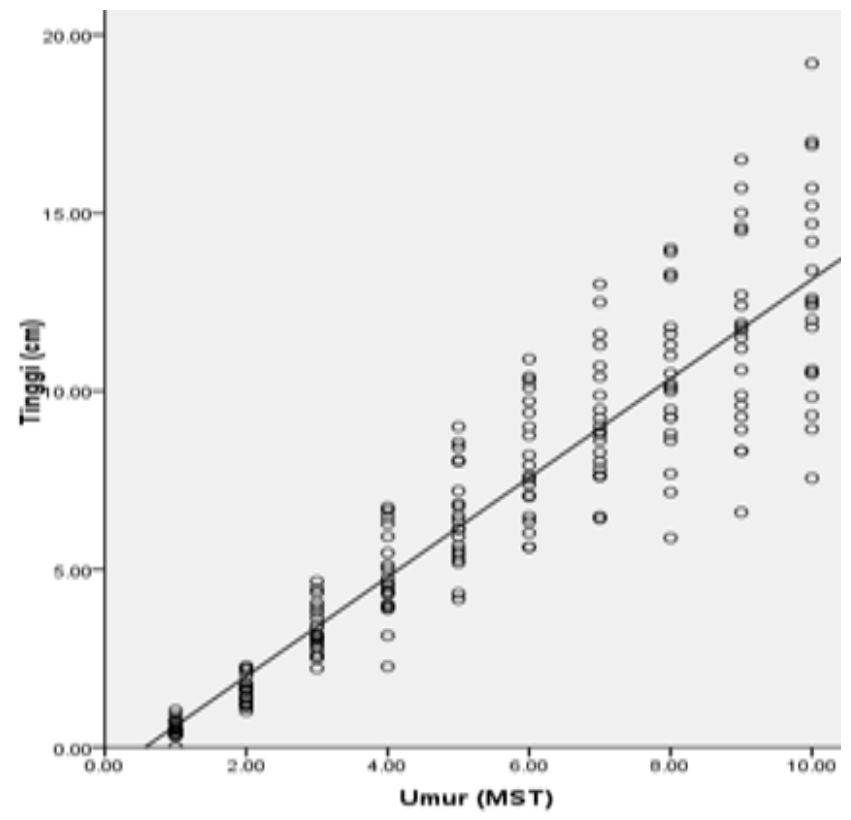

Gambar 1. Grafik hubungan umur terhadap rata-rata tinggi bibit kelapa sawit.

Tanaman kelapa sawit memiliki pertumbuhan yang unik ketika masih dalam masa pertumbuhan vegetatif sehingga diameter batang dapat dijadikan parameter pada masa pembibitan. Batang kelapa sawit mengalami pembengkakan pangkal batang (bole) yang disebabkan internodia (ruas batang) dalam masa pertumbuhan awal tidak memanjang sehingga pangkal-pangkal pelepah daun yang tebal berdesakan. Bongkol batang ini membantu memperkokoh posisi pohon pada tanah agar dapat berdiri tegak. Kenaikan pertumbuhan diameter dapat terlihat pada grafik berikut.

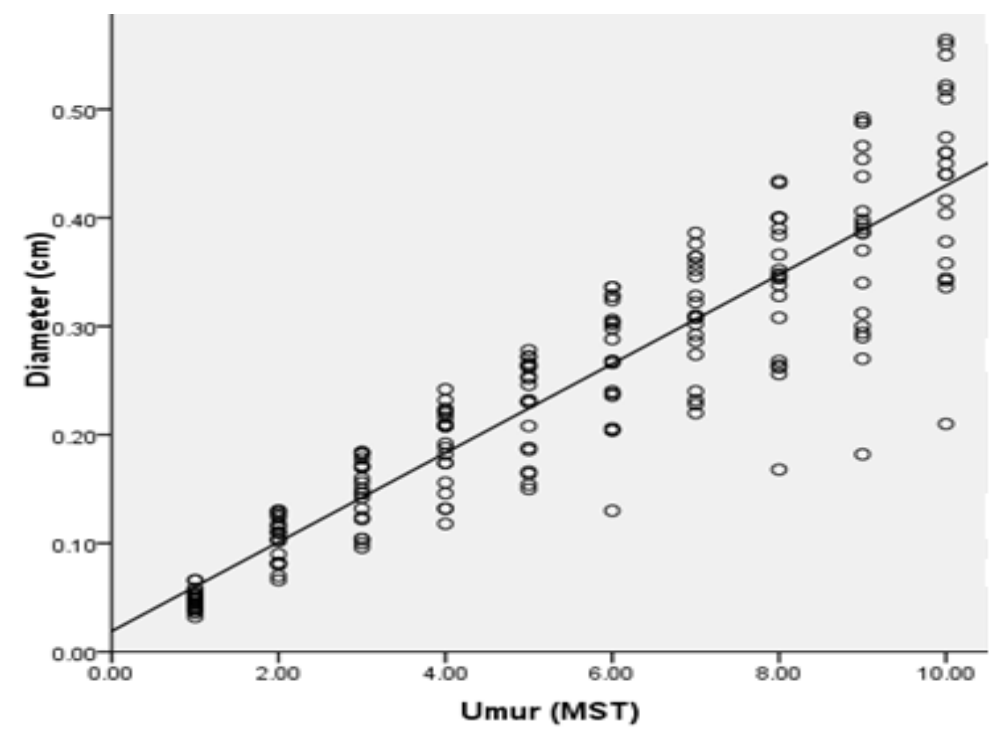

Gambar 2. Grafik hubungan umur terhadap rata-rata diameter bibit kelapa sawit

Hasil pengamatan di lapangan terlihat bahwa diameter batang bibit kelapa sawit pada 1 MST hingga 10 MST tidak mengalami kenaikan yang menunjukkan bahwa pemupukan dapat memberikan penambahan ukuran diameter batang yang besar. Pertambahan diameter bibit diduga lebih signifikan pada saat pengamatan selesai (main nursery).

Jumlah daun merupakan salah satu penanda pertumbuhan vegetatif yang dapat diamati secara langsung. Secara sederhana dapat dijelaskan apabila pertumbuhan vegetatif suatu tanaman baik, diharapkan mampu memberikan produksi yang tinggi karena hasil fotosintesis yang memadai untuk memasok energi bagi tanaman. Begitu juga dengan tanaman kelapa sawit, dengan adanya pertumbuhan daun yang baik, diharapkan nantinya akan memberikan hasil produksi yang tinggi pula.

PPKS (2000) menyatakan bahwa variasi pertumbuhan bibit dalam kelompok dapat terjadi karena variabilitas genetik, aplikasi pupuk yang 
tidak merata, penyiraman yang buruk serta variabilitas tanah. Dari grafik di atas juga dapat dilihat bahwa persamaan yang didapatkan adalah persamaan regresi linier. Hal ini dikarenakan waktu pengamatan yang sangat singkat sehingga model yang digunakan belum begitu terlihat.

Selama penulis melaksanakan kegiatan penelitian, pengamatan hanya dilakukan pada kegiatan pembibitan awal (pre nursery). Penulis tidak mendapatkan standar pertumbuhan vegetatif untuk pembibitan awal ini, sehingga penulis membandingkan pertumbuhan vegetatif bibit varietas DxP (L) PT. Socfindo dengan penelitian Hidayat (2010) tentang pertumbuhan vegetatif bibit varietas Pusat Penelitian Kelapa Sawit (PPKS) yaitu varietas Simalungun dan Langkat. Tabel 2 menunjukkan pertumbuhan bibit kelapa sawit di PPKS dan Bangun Bandar

Tabel 5. Pertumbuhan vegetatif bibit kelapa sawit di PPKS dan Bangun Bandar

\begin{tabular}{|c|c|c|c|c|}
\hline \multirow{3}{*}{ Peubah } & \multirow{3}{*}{ Umur (MST) } & \multicolumn{2}{|c|}{ PPKS*) } & \multirow[t]{2}{*}{ Bangun Bandal } \\
\hline & & & rietas & \\
\hline & & Simalungun & Langkat & $\mathrm{DxP}(\mathrm{L})$ \\
\hline \multirow[t]{6}{*}{ Tinggi bibit } & 4 & 6.59 & 6.62 & 5.86 \\
\hline & 5 & 8.22 & 8.38 & 8.22 \\
\hline & 6 & 9.89 & 10.13 & 9.60 \\
\hline & 7 & 11.30 & 11.49 & 11.4 \\
\hline & 8 & 12.74 & 12.78 & 13.06 \\
\hline & 4 & 0.25 & 0.25 & 0.24 \\
\hline \multirow[t]{4}{*}{ Diameter Batang } & 5 & 0.29 & 0.29 & 0.28 \\
\hline & 6 & 0.31 & 0.32 & 0.32 \\
\hline & 7 & 0.35 & 0.36 & 0.37 \\
\hline & 8 & 0.39 & 0.39 & 0.42 \\
\hline \multirow[t]{5}{*}{ Jumlah daun } & 4 & 1.09 & 1.07 & 1.34 \\
\hline & 5 & 1.26 & 1.20 & 1.70 \\
\hline & 6 & 1.44 & 1.41 & 2.14 \\
\hline & 7 & 1.59 & 1.59 & 2.42 \\
\hline & 8 & 1.71 & 1.74 & 2.74 \\
\hline
\end{tabular}

Keterangan $\quad:{ }^{*}$ ) Pertumbuhan vegetatif varietas Simalungun dan Langkat diperoleh dari PPKS dalam skripsi Hidayat (2010).

Dari Tabel 2 dapat diketahui bahwa tinggi bibit pada varietas Socfindo tidak berbeda dengan tinggi bibit hasil penelitian, kecuali pada saat umur 8 MST tinggi bibit varietas di kebun Bangun Bandar (13.06 cm) lebih tinggi dibandingkan dengan varietas PPKS $(12.74 \mathrm{~cm}$ dan $12.78 \mathrm{~cm})$. Bahan tanam Bandar Bangun mempunyai karakteristik dan keunggulan pertumbuhan meninggi yang lambat dengan ratarata laju pertumbuhan $50 \mathrm{~cm} /$ tahun (Socfindo, 2012). Begitu pula diameter batang bibit pada varietas Socfindo tidak berbeda dengan varietas di PPKS yaitu memiliki rata-rata $\leq 0.5 \mathrm{~cm}$. Namun, jika dilihat pada jumlah daun, varietas PT. Socfindo memiliki jumlah daun yang lebih tinggi dibandingkan dengan varietas di PPKS. Hal ini juga menjadi keunggulan pada varietas Socfindo karena pada umur 2.5 bulan bibit varietas DxP unggul Socfindo telah memiliki 3-4 helai daun sehingga dapat dipindah tanam ke main nursery maupun diangkut pembeli.

\section{Seleksi Bibit}

Pembibitan kebun Bandar Bangun sangat menjaga kualitas bibit yang dihasilkan, sehingga diperlukan seleksi bibit yang ketat untuk mencegah bibit yang bermutu rendah.
Pelaksanaan seleksi bibit di pre nursery dilakukan setiap satu bulan sekali, tetapi seringkali kebun pembibitan melakukan seleksi pada saat menemukan bibit abnormal di luar waktu yang telah ditetapkan. Seleksi ini dilakukan hingga bibit diangkut oleh pembeli. Bibit yang telah dinyatakan abnormal, kemudian dipisahkan dan dimusnahkan dengan cara di cincang.

Abnormalitas bibit di prenursery yang paling sering terjadi adalah daun berpilin (twisted leaf). Hal ini disebabkan karena ketika dilakukan penanaman, posisi plumula dan radikula terbalik, sehingga tunas berkembang memutar dan menjadi berpilin. Selanjutnya yang banyak dijumpai adalah daun berkerut (Crinkle leaf) yaitu bibit dengan pertumbuhan daun yang mengkerut terhambat di bagian tengah yang menyebabkan pertumbuhan daun terhambat. Hal ini dapat disebabkan oleh faktor genetik dan lingkungan (khususnya cekaman kekeringan). Selain itu, dilapangan juga sering terlihat bibit terkena serangan penyakit. Beberapa serangan penyakit Curvularia sebaiknya dipisahkan, dibuang dan dimusnahkan. Untuk abnormalitas lainnya sangat jarang ditemui di pembibitian kebun Bnadar Bangun ini.

Menurut PPKS (2003), perbedaan pertumbuhan bibit di pembibitan dapat 
disebabkan oleh faktor genetis dan perbedaan kultur teknis yang diterima masing-masing bibit. Kegiatan seleksi diharapkan hanya pada tanaman abnormal yang disebabkan oleh faktor genetik saja, sehingga diusahakan tidak terdapat kesalahan kultur teknis yang dapat menyebabkan timbulnya tanaman abnormal.

\section{KESIMPULAN}

Kegiatan penelitian yang penulis lakukan telah meningkatkan pengetahuan tentang budidaya tanaman kelapa sawit, memperoleh pengalaman dan keterampilan kerja sebagai KHL, pendamping mandor, dan pendamping asisten dalam pengelolaan kebun kelapa sawit baik secara teknis maupun manajerial, khususnya dalam aspek pembibitan.

Secara umum, pengelolaan pembibitan di kebun ini sudah berjalan dengan baik. Persentase bibit yang tumbuh pada minggu ke-2 hingga minggu pengangkutan bibit yang dijual mencapai 95.98\% sehingga kecambah yang ditanam sangat bagus digunakan sebagai bahan tanam. Faktor kematian bibit diantaranya disebabkan dari faktor kesalahan manusia (human error) yang kurang hati-hati pada saat proses penanaman berlangsung. Jenis pekerjaan harian tanpa target hasil yang diterapkan di pembibitan kurang efektif dalam kuantitas hasil yang dicapai, serta kurangnya pengawasan yang dilakukan oleh mandor pada saat pelaksanaan kegiatan di lapangan.

\section{DAFTAR PUSTAKA}

Direktorat Jenderal Perkebunan. 2010. Luas Perkebunan dan Produksi kelapa Sawit di Seluruh Indonesia. [Internet] [diunduh 2012 Feb 15] tersedia pada www.ditjenbun.deptan.

go.id/index.php/teknik-budidaya.html.

Effendi, D. 2010. Pengelolaan Pembibitan Tanaman Kelapa Sawit (Elaeis guineensis Jacq.) di PT. Jambi Agro Wijaya, Sarolangun-Jambi.

[skripsi]. Program Sarjana, Institut Pertanian Bogor. Bogor. 70 hal.
Hidayat, T. 2010. Penyiapan Benih Kelapa Sawit (Elaeis guineensis jaqc.) dalam Pengadaan Bahan Tanaman di Pusat Penelitian Kelapa Sawit (PPKS) Marihat, Sumatera Utara. [skripsi]. Program Sarjan, Institut Pertanian Bogor. Bogor. 84 lembar.

Mangoensoekerjo, S. Dan H. Semangun. 2008. Manajemen Agribisnis Kelapa Sawit.Yogyakarta (ID) : Universitas Gajah Mada press.

Pahan, I. 2010. Kelapa Sawit : Manajemen Agribisnis dari Hulu Hingga Hilir. Jakarta (ID): Penebar Swadaya

PPKS. 2000. Buku Lapangan Seri Tanaman Kelapa Sawit Volume 1 : Pembibitan. Pusat Penelitian Kelapa Sawit. Medan.

2003. Budidaya Kelapa Sawit. Dalam L. Buana, D. Siahaan, dan S. Adiputra (Eds). Kultur Teknis Kelapa Sawit. Pusat Penelitian Kelapa Sawit. Medan.

2006. Potensi dan Peluang Investasi Industri Kelapa Sawit di Indonesia. Dalam Latif, S (Ed). Potensi dan Peluang Investasi Industri Kelapa Sawit di Indonesia. Pusat Penelitian Kelapa Sawit. Medan

Sutarta, E. S., Winarna, dan N. H. Darlan. 2005. Penigkatan Efektivitas Pemupukan Melalui Aplikasi Kompos TKS pada Pembibitan Kelapa Sawit. Pertemuan Teknis Kelapa Sawit 2005. PPKS. Medan. 119-132.

Sastrosayono, S., 2008. Budidaya Kelapa Sawit. Edisi kedua belas. Jakarta (ID): Agromedia Pustaka.

Sukamto, ITN. 2008. 58 Kiat Meningkatkan Produktivitas dan Mutu Kelapa Sawit. Jakarta (ID): Penebar Swadaya.

Socfindo. 2012. Varietas benih. [Internet] [diunduh 2012 Jul 03] Tersedia pada http://www. PT. Socfindo.co.id 